This item was submitted to Loughborough's Research Repository by the author.

Items in Figshare are protected by copyright, with all rights reserved, unless otherwise indicated.

\title{
Lean in UK Government: internal efficiency or customer service
}

PLEASE CITE THE PUBLISHED VERSION

http://dx.doi.org/10.1080/09537287.2012.666899

\section{PUBLISHER}

(C) Taylor \& Francis

\section{VERSION}

AM (Accepted Manuscript)

\section{PUBLISHER STATEMENT}

This work is made available according to the conditions of the Creative Commons Attribution-NonCommercialNoDerivatives 4.0 International (CC BY-NC-ND 4.0) licence. Full details of this licence are available at: https://creativecommons.org/licenses/by-nc-nd/4.0/

\section{LICENCE}

CC BY-NC-ND 4.0

\section{REPOSITORY RECORD}

Radnor, Zoe J., and Robert Johnston. 2019. "Lean in UK Government: Internal Efficiency or Customer Service”. figshare. https://hdl.handle.net/2134/15859. 


\section{Lean in UK Government: Internal Efficiency or Customer Service?}

\section{Abstract}

This paper draws on service operations and Lean management in considering the relationship between internal service processes and customer service in public sector organisations. It draws on extensive evidence from two case studies of large UK Government departments to illustrate that whilst public service organisations recognise that methodologies such as Lean improves their internal processes to date they have not linked this to value or customer service. The paper presents a model which shows that public service organisations are driven towards internal operations improvement due to the efficiency agenda leading to a process focus, rather than a market driven approach focusing on the customer. The paper argues that although this starting point is not necessarily bad in order to sustain improvement after initial gains there is a need to focus on both process and customer. The paper therefore contributes and extends the discussion on the adaptation of Lean for a public sector context.

Key words: Lean, efficiency, customer service, process, public sector

\subsection{Introduction}

It has been suggested that poor service is usually the result of it not being designed correctly and that most problems (around $70-90 \%$ ) are recurrent and built into internal service processes, albeit inadvertently (Edvardsson and Olsoon 1996). Thus it is argued that by improving their internal operations organisations will not only make them more efficient but also improve their service to external customers. However, drawing on evidence from two case studies of large UK Government departments this paper will illustrate that whilst public service organisations recognise that methodologies such as Lean improves their internal 
processes to date they have not linked this to value or customer service. Even though there appears to be a common acceptance in the literature that the quality of internal processes and internal service is a key influencer of, and contributor to, the quality of external service (see for example (Gremler et al. 1994; Parente et al. 2002; Zeithaml et al. 2008) this paper will argue that public services are currently taking a production or goods-dominant approach to process improvement rather than a service approach. However, it will use this evidence to extend the debate on how Lean can be adapted for a public sector context.

The main benefits of improving internal operations have been shown to include increased customer satisfaction through better customer service/quality (see for example(Gremler et al. 1994; Zeithaml et al. 2008), improved staff attitudes, staff retention and compliance as well as an improved competitive position (Lings and Greenley 2005), and improved financial performance (Heskett et al. 1994; Heskett et al. 2003).

Recently many public services including Health (Guthrie 2006; Fillingham 2007), Central Government (Radnor and Bucci 2007) and Local Government (Seddon 2004; Office of the Deputy Prime Minister 2005) organisations within the UK and the US (Krings et al. 2006) have attempted to improve their internal operations due to the pressure to increase efficiency. Initially, the Gershon review in 2004 (Gershon 2004), then the Efficiency Agenda (HM Treasury 2008) and most recently the Operational Efficiency Report (H M Treasury 2009) stipulated that potential savings of around $£ 10$ billion a year should be sought over a period of three years. In response to the need to be efficient much of the public sector has implemented a set of management techniques around business process improvement methodologies, particularly Lean and Six Sigma (Radnor 2010).

However, as these public sector organisations focus on improving internal operations to achieve increased efficiency, a key question arises; are they focusing on the customer needs and has customer service improved? In others words, are they recognising the relationship between the internal and external processes and services? While this has been considered in the for-profit arena (see for example (Rust et al. 1995; Pritchard and Silvestro 2005), the objective of this paper is to explore this within public sector organisations. 
Through extensive case study research in two large government departments this paper will explore the impact and focus on the customer whilst implementing process improvement through assessing the drivers and focus for improvement.

The paper will begin by considering the importance of customer focus. The paper then moves on to consider the business process improvement methodology the government departments have implemented - Lean. Then after outlining Lean in Public Services the paper will explain how the case studies were conducted before presenting the findings in two large UK Government departments. Finally, the discussion and conclusion section will argue that to sustain improvement within the public sector organisations need to focus on not only on the internal processes but also the customer/ value to enhance the service.

\subsection{Customer Focus}

Focusing on the customer and striving to deliver good (or appropriate) levels of service is something most organisations claim to be concerned with, whether in the private, public or even voluntary sectors (Pine and Gilmore 1998; Berry et al. 2006). However there is a view that 'customer focus' is poorly understood and so does not deliver the expected benefits to either the organisation or its customers (Vandermerwe, (2004). Although becoming customerfocused does not mean the firm has to become completely 'customer orientated' as Prahalad and Ramaswamy (2006) suggest customer focus means the customer becomes part of the unit of analysis, part of the value creation, and that the organisation works at finding opportunities (with the customer) to create (i.e. co-create) greater value for both the customer and the organisation.

Some organisations do have a reputation for having developed a customer focus and delivered improved/different or exceptional service to their customers. The story of the transformation of IBM from a product business to one which now sells services with a clear focus on a very different set of customers is well known and was played out over a period of over 13 years (Slater 1999). 
Key customer focus issues such as service quality, customer satisfaction and the customer experience have been researched primarily from a for-profit perspective (see for example(Ding et al. 2010; Zomerdijk and Voss 2010). However, there has been some exploration in a public sector context (see for example (Price and Brodie 2001; Micheli and Kennerley 2005; Davis 2006). Although there is no common and accepted set of activities to achieve customer focus and good (or appropriate) levels of service, there are several key elements that are prevalent in the literature including; knowing who the customers are, their expectations, requirements and value opportunities (Vandermerwe 2004); developing, articulating and sharing a (compelling) service concept (Clark et al. 2000; Goldstein et al. 2002); designing and 'engineering' both the service and the experience to deliver the concept (Verma et al. 2002; Zomerdijk and Voss 2010); creating a service culture and customer-focused mindset (Skalen and Strandvik 2005; Johnston 2008) and; measuring and assessing the service from the customer's point of view (Olsen and Johnson 2003).

The importance of a customer focus involving developing a collaborative and open approach to working with customers in order to better understand and deliver what customers value has been a recent theme in the marketing and change management literatures (see for example Carnall 2007; Piercy and Rich 2009)). These perspectives have converged to form a new dominant logic for marketing, a service-dominant (SD) logic (Vargo and Lusch 2004; Lusch et al. 2007) which is concerned with the creation, or rather co-creation, of value-in-use (see also Edvardsson et al. 2005; Edvardsson et al. 2010). This is in contrast to goods-dominant (GD) logic where the focus is on production, with discrete transactions and outputs, usually tangible (Vargo and Lusch 2004). This production, back-office, focused approach is sometimes, and we would argue incorrectly, seen as the domain of a Lean approach.

\subsection{A Lean Approach}

Originating from the Toyota Motor Corporation, Lean (also referred to as the Toyota Production System, TPS) is considered to be a radical alternative to the traditional method of 
mass production and batching principles for optimal efficiency, quality, speed and cost (Holweg 2007). The history of Lean Production has been widely discussed, and shall not be recounted here (refer to (Ohno 1988; Womack et al. 1990; Womack and Jones 1996; Fujimoto 1999; Hines et al. 2004; Holweg 2007) for comprehensive reviews on TPS and Lean Production).

Although a number of authors, including Womack and Jones (1996), state that Lean can be used in a pure service environment relatively few private services sector examples exist. The term 'Lean Service' (Bowen 1998) has been developed to reflect the improvement in administration or office processes often within manufacturing organisations. Piercy and Rich (2009) argue that the application of Lean approaches in a service context has been limited to where a physical product exists (e.g. retail supply chain management) or in call centres where the nature of the process and improvements have been shown to support a Lean approach(Piercy and Rich 2009).

Although Lean is sometimes simply associated with the elimination of waste (Shah and Ward. 2007), it could be argued that Womack and Jones, regarded by most as the originators of the term 'Lean Thinking', captured a dual customer and process-focused approach in their five principles of Lean (Womack et al. 1990; Womack and Jones 1996):

1. Define value from the customer's point of view,

2 Identify the value stream for each product/ service providing that value and, challenge all of the wasted steps,

3 Make the product flow continuously,

4 Introduce pull between all steps where continuous flow is impossible,

5 Manage towards perfection so that non-value adding activity will be removed so that the number of steps, amount of time and information needed to serve the customer continually falls.

Even though the process improvement appears to dominate four of the principles a customer focus is considered as the first principle (Womack and Jones, 1996). Shah and Ward note that 
"In 1996 Womack and Jones crystallised value as the first principle of Lean thinking ... As such Lean has moved away from a merely shop-floor focus on waste and cost reduction to an approach that contingently sought to enhance value (or perceived value) to customers by adding product or service features and/or removing wasteful activities" (Shah and Ward 2007, p 995). It could be argued, therefore, that Lean aims to embody both process improvement and enhanced customer service.

\subsection{Lean in Public Services}

What has become known as New Public Management (NPM) (Christensen 2001), has been encouraging the public sector to adopt private sector practice such as change management processes, strategic management models, quality management and Lean approaches (Ferlie 2002; Pollitt and Bouckaert 2004; Bhatia and Drew 2007). In response to the Efficiency Agenda new concepts like Lean have now become widely accepted in the public sector (Radnor 2010).

So how are public sector organisations implementing and adapting Lean and what is the impact? Table 1 draws on some examples of the implementation of Lean in, mainly UK, public services showing both the approach and the impact. The table also illustrates the breadth of the implementation across government departments, health and local government organisations.

Table 1: Examples and Impact of Lean Implementation in the Public Sector around here

Many of the examples illustrate dramatic impacts of implementing Lean. These include tangible outputs such as reduction of (processing or waiting) time, increase in quality through a reduction of errors, reduction in costs (through less resource) (Silvester et al. 2004) as well as intangibles such as increased employee motivation and satisfaction and, increased customer satisfaction (Radnor and Boaden 2008). 
Some would suggest that this is not surprising as many of process improvements are 'low hanging fruit' as public services have only just begun to develop thinking in terms of processes (Radnor and Walley 2008). Others would argue that the focus of Lean in public services is around reduction of costs and not principally on customer needs and satisfaction (Seddon and Brand 2008). So is this the case? Has Lean implementation in public services mainly focused on internal process improvement and, not customer needs or service? This paper will aim to investigate this by considering the implementation of Lean in two large government departments.

\subsection{Method}

The UK is a rich source of information about public service 'reform' and change over the last two decades (Boyne et al. 2003). It provides a valuable context in which to explore how practices 'take', or are adapted or adopted, and for what reasons, across a whole institutional field. In the UK, $18 \%$ of the workforce is employed in the public sector (MacGregor 2001) with around half of the workforce, or 2.8 million, working in local government and 1.5 million in the health services (Massey 2005). And, importantly, everyone is a user/consumer of public services.

This paper is based on evaluative research which has looked into how Lean is applied within two large government departments; HM Customs and Revenues and HM Court Service. Interviews were carried out with over 480 individuals across the organisations through a combination of individual interviews and focus groups. Table 2 outlines the location and number of interviews conducted. Interview schedules, based around common thematic guides, were developed for 'level' of staff in the organisation i.e. senior grades and front line staff. Normally interviews with senior and middle management occurred individually whereas focus groups with the 'front line' staff could consist of up to eight members. 
In relation to the focus of this paper, the degree to which the internal processes have changed, customer needs were taken into account and, the impact the changes have made on the customer service the following interview questions will be considered:

- What would you describe as the impact of the Lean programme?

o What has been the impact on performance?

o What outcomes have occurred as a result of Lean?

- Who is your customer? What are their requirements?

o How has Lean affected customer interaction and improved customer service?

\section{[Table 2 around here]}

All interviews were transcribed and additional 'reflective notes' were developed during the case study. Evaluative research draws from the same methodological principles and practice as interpretive research therefore the transcribed interviews were rigorously coded and classified using the six step procedure (Radnor 2002). Radnor's technique for analysing and interpreting data follows six key steps, 1) topic ordering, 2) constructing categories, 3) reading for content, 4) completing coded sheets, 5) generating coded transcripts, and 6) analysis to interpretation. Radnor's (2002) data analysis approach is designed for the researcher to code whilst allowing the qualitative data to be linked, shaped and searched. Through using this method of analysis there is a level of sensitivity to detail and context, as well as accurate access to information. The material was written up as individual case study reports which were validated by each organisation (Radnor and Bucci 2007; Radnor and Bucci 2010).

\subsection{Findings}


This section will begin by giving an overview of the two organisations (HM Revenue and Customs and HM Court Services) and their Lean Programme. Then the findings related to impact on the process and customer service will be presented.

HM Revenue and Customs (HMRC) was established in April 2005 as a nonministerial department, accountable to the Chancellor of the Exchequer. HMRC is responsible for administering taxes (both direct and indirect), National Insurance contributions and Customs duties. HMRC also pays and administers tax credits and child benefits. At the time of the case study in 2007 its operational units employed over 70,000 staff across over 100 sites around the UK focusing on delivering services such as processing, local compliance and customer contact. Almost every UK individual and business is a direct customer of HMRC. HMRC has over 30 million individual customers, UK citizens, and four million business customers who all pay taxes.

Pacesetter (HMRC's name for the Lean programme) was developed by HMRC Processing to improve efficiency and customer service by delivering a $30 \%$ improvement in productivity, reduce backlogs and inconsistencies and ensure that HMRC Processing is amongst the best UK processors and becomes the UK Government's Processor of choice. Lean in HM Revenue and Customs (HMRC) began in earnest in April 2006 across a number of sites (Radnor and Bucci, 2007). It consisted of introducing revised processes in the four key customer facing operations at each of the sites. Introducing performance boards which reflected the teams' performance, resource planning, targets and, problems. These were supported by daily meetings (10 minutes each morning) to motivate the staff to reflect on the achievements of the previous day, plan the days work and resolve any outstanding problems or issues with the process. Other tools were also introduced to support ongoing problemsolving (Radnor 2010).

Her Majesty's Courts Service (HMCS) is an executive agency of the Ministry of Justice (MoJ). Its remit is to deliver justice effectively and efficiently to the public through the management of magistrates' courts, the Crown Court, county courts, the High Court and Court of Appeal in England and Wales. At the time of the research in 2010 HMCS was 
structured into 18 areas within seven regions, together with the Royal Courts of Justice group whose role included the administration of the Court of Appeal, High Court and Probate Service. HMCS was responsible for 664 properties of which 530 are operational courthouses with 2,863 courtrooms and employed around 18,000 staff. Their business strategy sets out the objectives for creating a court service that is modern, efficient and fit for the 21st century. Their strategic goal focuses on access to justice, reducing cost, reducing delay, leading to a transformation of services.

To support this HMCS was in the process of rolling out a three year Lean programme, launched in Autumn 2008, whereby it will carry out an 'initial touch' of all courts in England and Wales by December 2011 (Radnor and Bucci 2010). All jurisdictions of court were involved and the programme was designed to be 'consultant' free focusing on developing internal capability in the form of change agents. These were HMCS staff which had undergone training through a Lean Academy. Each court started with a Lean event to introduce revised processes through Standard Operating Procedures (SOPs) and new practices into the courts. Like HMRC these practices included the introduction of Team Information or Performance Boards for every team to use to manage workload allocation, identify problems within the process, skills of team members and successes achieved. The performance boards were to be used in conjunction with regular short (10 -15 minutes) daily team meetings, led by the team leader to communicate the current day's work, discuss any problems that have been encountered and to clarify points of common interest.

\subsection{HM Revenues and Customs (HMRC)}

One aim of the Lean implementation was to improve the performance of sites. The performance of sites was measured on the basis of number of cases/claims processed per day (productivity), the number of cases/claims processed correctly (quality) and the time taken to process a case/claim (lead time). There was an understanding that key 
performance indicators i.e. targets, were set for each of these measures and teams were judged in relation to how they performed against these targets. Other outcomes and impact included the changing role of managers, teamworking and problem solving.

Whilst senior managers are undertaking different tasks, the grade of staff that has been most affected by Lean was the front line manager. The role now focuses more on management tasks and challenging staff regarding performance and less on managing people. Teamworking was one of the success stories from the Lean implementation due to the fact they met on a daily basis to discuss performance. Many staff highlighted this as a positive aspect of Lean and could not envisage a time when teams would again operate as they did before Lean. Where problem solving was taking place regularly using a variety of tools, implementing solutions and spreading solutions across the site staff were willing to get involved and highlighted this as a positive aspect of Lean.

It was felt that the word 'process' was used more widely, staff were aware they were part of a process, teams focused mainly on one process and, the business talked about process owners as well as standard processes. It was also recognised that working focused around processes was improving productivity and quality. It was also felt that by developing a process view and working to a standard made it easier to increase awareness of the impact of unplanned absence and better problem solving.

In the majority of sites, the senior managers referred to the customer and saw the need to deliver a better customer service and the important role that Lean should have in this. However, many were doubtful whether the front line staff understood this but efforts were being made to increase the understanding of the relationship between the Lean implementation and customer.

"Lean is a process, which is going to help us achieve a better customer outcome. We find it difficult in HMRC to get that concept in an office like this we never see the customer, some of my people never talk to the customer, so it's a bit of paper or a screen. We really have got to go back to basics with our customers" (Middle Manager) 
"Sometimes we forget there is a customer at the other end. I think Lean has highlighted that. Sometimes we are in danger of forgetting that the paper we are dealing with, actually represents the customer. We have more of a realisation about customer focus than we had. I am not saying that we are there yet, but we are getting there" (Front line manager)

Many of the senior management referred to the customer and used this term during interviews. Front line staff referred to the taxpayer and not the customer. In their view, the tax payer was not a customer because customers have a choice of service providers and tax payers do not.

"We don't actually use the word but we hear it more often now. A normal customer would have a choice but the tax payers don't have a choice" (Front line staff)

"The customer requests a service, the tax payer is told they have to pay. We are supposed to call them customers, but they are not" (Front line staff)

These views were fairly consistent even though managers recognised that customer focus was important for Lean. The customer requirement was to have a claim processed on time and accurately. However there was recognition that they had 'no choice' in who they could go to for this service so they were different from customers who had a choice.

"Because [HMRC] doesn't have a competitor, we can turn around and be more difficult with customers. The bottom line is they can't go anywhere else" (Front line manager)

No individual at any site could point to any evidence that highlighted what the customer/claimant/trader wanted of their service from HMRC. They all claimed to know i.e. 
"it's what I would expect" or "it's obvious" and highlighted that HMRC carries out surveys, although no one claimed to have seen one. There was an acknowledgement in all sites that Lean had increased the quality for the customer. However, quality had improved because there were now more quality checks being undertaken with dedicated quality managers who gave immediate feedback to staff so that they could learn from their mistakes.

"From a customer point of view, the one thing that l've found from the start when we were doing self-assessment returns is that Lean has produced better quality work, which has got to be good for the man outside. It has a benefit to the customer because it is done, in this particular site more correctly than it was pre Lean" (Senior Manager)

The senior managers at many sites acknowledged that there were external and internal customers. The claimant/taxpayer is the external customer, while other HMRC offices, other processes or colleagues would be the internal customers. Only in some sites was this view shared by front line staff. In many sites, the internal customer was called a colleague. Many staff at these sites did not accept the concept of an internal customer.

\subsection{HM Court Services}

The main impacts highlighted by HMCS staff included increased team performance which involved more specifically increased productivity to hit targets more often.

"The big success of Lean has been that we are hitting targets more." (Senior Manager)

Also there was reduced time to undertake specific duties thereby reducing the amount of wasted time and releasing capacity. Sites were asked what they had done with the extra time they had released. At one large site where a lot of time had been released, it was highlighted that as staff left or retired, they were no longer being replaced, so their duties were being absorbed by the remaining staff. Therefore it was acknowledged that more work 
was being done with less staff. In three courts it highlighted that the released time has been used to improve the skills of staff or spend time to make additional process improvements.

"We have reduced the time it takes to complete a process. With the extra time obtained we look to make further improvements or to do some training of staff" (Senior Manager)

There was a feeling amongst all court managers that the performance of the court had improved and that staff were doing more work on a daily basis. However there was not much performance monitoring and measurement to back this up. Indeed there was little quantitative evidence of the results. There were many qualitative impacts highlighted by staff although as with the quantitative impacts, there was little actual data to support these statements. The main qualitative impacts included better teamworking and more multiskilling was highlighted at twelve sites due to the fact that regular meetings were held by teams to discuss work.

"There is more teamworking now and staff are moving around teams more often when the teams need additional resource. This is contributing to more multiskilled staff" (Middle Manager)

Also there was more discussion about problems being held between team members and more informal problem solving being undertaken at team meetings, with some evidence of cross team problem solving occurring.

"We are discussing problems and work issues within the team a lot better. There are also elements of cross team problem solving occurring as we now have the problem solving hub." (Front line Manager)

Lean did appear to impact positively upon the understanding of the end to end processes i.e. how work moved around the court. There was even recognition in four sites that the process went beyond their department and was linked closely with the work of legal advisors, some of the judiciary, ushers and even outside agencies. 
"Yes the understanding of process has changed. This is shown by staff working more as a team i.e. ushers are working with the other offices" (Manager)

In all sites, it was generally acknowledged that those staff who had attended Lean events had a better understanding of the end to end process that those staff who had not.

"The understanding of process here has changed, especially for those who attended the Lean event. They were able to see how the work linked together across the court. But the other staff need to attend more Lean events to get a better understanding" (Senior Manager)

Staff in all sites understood that they were carrying out a service, whose end result would impact upon a 'customer' although in all sites the word 'customer' was not used especially by team members. When asked who the customers were, staff would name agencies they worked with including the police, Probation Service, Crown Prosecution Service, the Children and Family Court Advisory and Support Service, the judiciary, solicitors, barristers and local authorities. They also highlighted that defendants, witnesses and the general public were customers. Although it was noted in three sites that the view of a defendant or other agencies as a customer was very difficult to perceive. HMCS senior managers recognised that Lean should focus on customer service, but that this had not always been the case.

"I think the whole focus of this has not always been around customer service" (Change Agent)

However, in all sites that acknowledged an improvement in a process, there was very little understanding of how this improvement had impacted upon the customer. Only in four sites had managers acknowledged that they were getting fewer complaints and queries from customers. In other sites staff were aware that their jobs had become more efficient but were unaware of the wider implications. It was assumed at five sites that because there had been 
an improvement in the process and targets were being met, customer service had improved. However the majority of staff interviewed felt there was uncertainty as to whether this improvement was evident for the external agencies or the general public.

"Customers are defined as anyone who used the courts, the defence solicitors, probation service, people in the public gallery etc. I doubt very much if they see any difference from Lean because it's principally in the back office" (Front line Manager)

Generally there was a feeling that Lean was improving customer service and more importantly, implementing Lean across agency boundaries would have a longer lasting impact. However there was no evidence to support any of these claims. Indeed a manager at one site explained that it was impossible to determine whether there had been any improvement in customer service because HMCS did not really know what the customer wanted.

"We think we understand what customers want but we really don't know. We haven't asked them. We think they want a faster service. We have improved the turnaround of resulting and post etc., so we assume they are more satisfied, but we don't really know for sure" (Middle Manager)

There was some direct collaboration with customers at three sites. Two sites held inter-agency workshops with other agencies. The workshops looked at systems and issues between all agencies in order to get a better perspective of inter-agency issues and tried to reduce elements that were not important or necessary and the duplication of work. Another site had done some inter-agency work with barristers, which had contributed to time savings of about 40 hours per month.

"I was involved in the inter-agency workshop. It was good and very interesting and we tried to resolve issues. But due to a lack of funding it was not taken forward despite enthusiasm and willingness to do so" (Front line staff) 


\subsection{Discussion}

Referring back to the literature at the start of the paper we suggest that there is a relationship between customer focus and process focus. We would argue that when considered together they can create a cycle of improvement (see Figure 1). We would also argue that if the focus is only on process (efficiency) then service (effectiveness) may well be compromised. Alternatively, by focusing only on the customer, inefficiencies or waste may be built in to the process. It is only by focusing on both aspects that sustained improvement will be achieved. So, in implementing Lean to what degree have HMRC and HMCS considered both the process and customer focus?

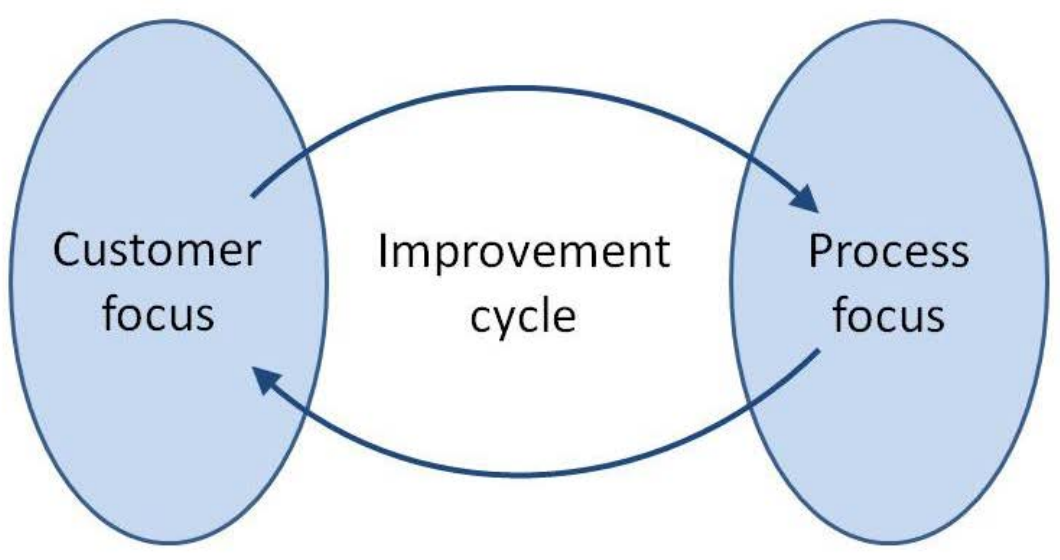

Figure 1: Sustaining improvement

In HMRC Lean impacted upon tools, structure, processes and behaviours. This has improved quality and productivity, made processes clearer and led to new ways of working by considering process design and introducing standard processes. Lean resulted in an increase in the quality of the work at all sites. There was a more structured approach to problem solving, which was welcomed by many staff. Staff had become more accountable regarding the way that they manage and many senior staff were more visible. Lean has 
made the managers manage by collecting statistical information, by looking at productivity and by challenging performance. Teamworking was generally acknowledged to be better under Lean with evidence of increased cooperating within teams, problem solving within teams and team responsibility for collecting and presenting information related to targets.

However, the attitude towards customers was fairly consistent across staff in HMRC, in that there was a clear distinction between senior managers and front line managers. Senior managers talked about improving the customer service, while front line staff talked about taxpayers who had no choice about their service provider. The majority of front line staff thought about customers as individuals who have a choice rather than individuals who can expect a level of service. The level of service the majority of staff thought customers required was 'quick and accurate' or 'quick and correct'. However, there was no evidence to support these views or to define what was meant by 'quick' or 'correct'.

In HMCS attitudes towards Lean were positive where Lean had big impacts on processes, especially if these impacts were immediate or resulted in 'quick wins'. These immediate impacts included; hitting targets more often, clearing work in the day and backlogs, discussing issues and solving problems on processes, empowerment to challenge the way work was done and to seek to make changes to reduce errors.

But in responding to the question 'who is the customer?' the response was often 'everyone'! When asked whether their requirements were understood the answer was 'yes high quality quick information'. It was encouraging that the concept of a customer was recognised and there was a perception of the need to provide a high level of service. However, it was clear there are assumptions regarding the requirements and that the 'voice of customer' has not been clearly articulated. There was no evidence to support what level of quality and timing of information would result in better processes and so happier customers.

If we refer back to the elements from the literature regarding developing a service dominant logic we can assess that little is understood within HMRC or HMCS on who the customers are, let alone their requirements. Meaning it is difficult to develop a service concept (Clark et al. 2000), engineer a process to deliver the concept (Verma et al. 2002), 
create a service culture (Johnston 2008) and, measure the service from a customers point of view (Olsen and Johnson 2003) (although other measures are being collected).

So, it appears that both HMRC and HMCS have both main gains in improving their internal processes and, both recognise the need to link this with customer service but neither appear to have made the leap by linking their internal operations to their external service delivery. The questions therefore are, why not? And, more importantly, does it matter?

Regarding the first question developed from the findings, why are these large public sector organisations not linking their internal operations to service delivery, the answer lies probably in the nature and structure of public services. Many papers explain the differences between the private and public sectors and private sector management and public management. The core of this debate is that the differences are so great that business practices cannot, indeed should not, be transferred to the public sector (Boyne 2002).

While it could be argued that public and private sectors require similar basic management functions, the different environment, context and constraints do affect the managerial role and the way they are performed (Mintzberg and Bourgault 2000). The public sector management is more complex, addressing key issues of equity, transparency and probity, within a political context (Wilson 1989; Osbourne and Gaebler 1993; Pollitt 2003). Due to these differences, it can be argued that simply adopting private management practices and language (such are market and customer) into public management may not lead to expected significant improvements (Radnor and Boaden, 2008).

However, referring to the case organisations in this paper we have seen some significant improvement driven by the need to meet the demands of the efficiency agenda. This agenda leading directly to budget cuts and reduction in resources (staff and facilities) has led to re-designing key processes which in turn have increased productivity, quality and even staff satisfaction. Radnor (2010) argued this may be case because many processes were so poorly designed it would not be difficult to achieve significant impact. In other words, the implementation of Lean may be on 'the fringes' of service transformation with results that lead to impressive efficiency gains in the short term but that, in most cases, may 
stall or fail to materialise into more widespread and sustained improvements due to the lack of understanding of the customer. However, who the customer is raises an interesting discussion in itself, as shown in the findings, which is beyond the scope of this paper except to say maybe by using the notion of 'value' could re-focus the debate (Radnor et al. 2011).

This leads to the second question posed in this discussion, does it matter that the starting point is process rather than customer? The answer is probably not in the short term as public services grapple with the concepts of Lean but maybe in the longer term. The difficulty in defining 'customer' as evidenced in the case studies and, the complex context may mean there is a challenge in the ability to create a link between internal operations, service delivery and customer satisfaction and value. Indeed, if the public sector does not or is not able to develop understanding of the value for the citizen/market as a driver any further development of Lean or process improvement may not be sustainable. This may mean that the agenda may always be on efficiency rather than effectiveness and indeed take a goods/production rather than service dominant logic.

\subsection{Conclusion}

Theoretical a fundamental to a Lean Approach is the determination of customer value then aligning the operational processes to deliver it in a coordinated and efficient way. Advocates of Lean would argue that without determining who is the customer and what does value mean for them, then any changes to operational processes, while being more efficient, are not likely to be effective. Above we raised the question, does this matter in public services? In the shorter term while public services are facing very challenging budget cuts reducing costs through internal efficiency may be a vital approach to take. No doubt the level of some services will be reduced in so doing. However, in the longer term this process focused approach could be detrimental in two ways. Firstly it will (continue to) undermine the level or provision of services provided to the public, despite the fact that the public continue to pay at past levels of local and national taxation. And secondly, it will miss the opportunity to 
develop strong internal processes linked to value, instead costs will be cut and processes made more efficient but not targeted at what the customer really values.

What the private sector seems to benefit from is creating a self-sustaining cycle of operational improvement, including both improved customer service and increasing efficient processes, due to the fact that there appears to be two drivers for improvement; the efficiency driver - the need to continually look to reduce costs and provide good returns to shareholders in increasingly difficult conditions, and the market driver - the need to be close to the market, understand what customers value and what they don't, coupled with pressures from competing organisations. Building on figure 1 we argue that these two drivers (see Figure 2) provide the impetus for both process improvement and better customer service which together create a longer term, sustainable, programme of operational improvement. The current public sector changes are clearly driven by the efficiency agenda and there does not appear to be a great understanding of the customer, their needs or what they really value. We would therefore predict that if this focus continues such approaches as 'Lean' are unlikely to be sustainable and could lead to a potential unnecessary decay in the quality of public services.

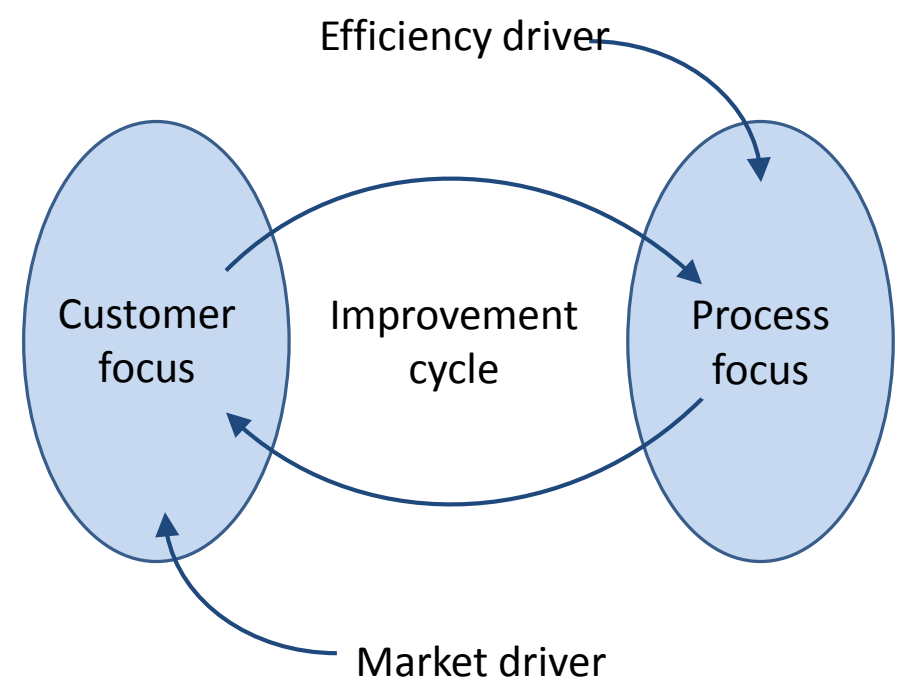

Figure 2: Drivers for sustainability 
Figure 2 also gives an opportunity to consider Lean in the context of the public sector. Even though Lean states that improvement should start with customer focus, which may be possible for private sector firms, the evidence presented finds that the main driver for public services has been the efficiency agenda. Therefore, for public services the theoretical ideal of starting with value or customer needs may not be possible. Therefore, we challenge the Lean theory in the context of the public sector suggesting that the starting point for improvement does not have to be the customer, although a cyclical relationship needs to be created between customer/value and process focus in order to sustain both efficient and effective operational improvement. This paper contributes to the ideas of adaption of Lean in the public sector by moving beyond the principle that customer needs have to be defined first through drawing on service management and Lean literature to develop a model which presents a cyclical relationship between process and customer focus. 


\begin{tabular}{|c|c|c|}
\hline Organisation & Methodology & Impact \\
\hline \multicolumn{3}{|c|}{ Central Government } \\
\hline $\begin{array}{l}\text { Ministry of } \\
\text { Defence (MOD) }\end{array}$ & $\begin{array}{l}\text { Lean practices to } \\
\text { improve the } \\
\text { efficiency of the } \\
\text { repair process }\end{array}$ & $\begin{array}{l}\text { A fall in the cost of support from } £ 711 \text { to } \\
£ 328 \text { between } 2002 \text { and } 2007 \text { and the } \\
\text { reduction of manpower by } 21 \% \text { (for one } \\
\text { aircraft). }\end{array}$ \\
\hline $\begin{array}{l}\text { Department of } \\
\text { Works and } \\
\text { Pensions (DWP) }\end{array}$ & Lean & $\begin{array}{l}\text { For one site (out of } 80 \text { ) employing circa. } 400 \\
\text { staff } 101 \text { improvement opportunities, } £ 575 \mathrm{~K} \\
\text { in cost savings, reduced customer journey } \\
\text { times including change of address to } 1 \text { day } \\
\text { from } 9 .\end{array}$ \\
\hline \multicolumn{3}{|l|}{ Healthcare } \\
\hline $\begin{array}{l}\text { Royal Bolton } \\
\text { Hospital }\end{array}$ & $\begin{array}{l}\text { Bolton Improving } \\
\text { Care Systems (Lean) }\end{array}$ & $\begin{array}{l}\text { Direct savings of } £ 3.1 \mathrm{~m} \\
\text { Death rate for patients fell by a third. } \\
\text { The time taken to process important } \\
\text { categories of blood fell from } 2 \text { day to } 2 \text { hours. }\end{array}$ \\
\hline $\begin{array}{l}\text { Nebraska Medical } \\
\text { Centre }\end{array}$ & $\begin{array}{l}\text { Lean principles to } \\
\text { redesign the work } \\
\text { area in the sterile } \\
\text { processing centre } \\
\text { and in the clinical } \\
\text { laboratories }\end{array}$ & $\begin{array}{l}\text { Reduced staff walking by } 167 \text { miles a year. } \\
\text { Reduce lab space by } 825 \text { sq } \mathrm{ft} \text { and specimen } \\
\text { processing turnaround time by } 20 \% \\
\text { Reduced manpower by } 11 \text { Full Time } \\
\text { Equivalents (FTEs), who were redirected to } \\
\text { other critical work. } \\
\text { Average length of stay decreased from } 6.29 \\
\text { days to } 5.72 \text { days. }\end{array}$ \\
\hline \multicolumn{3}{|c|}{ Local Government and Others } \\
\hline $\begin{array}{l}\text { Connecticut } \\
\text { Department of } \\
\text { Labour }\end{array}$ & Lean & $\begin{array}{l}119 \text { steps eliminated, redesigned, or } \\
\text { automated; } 1,181 \text { cycle time hours } \\
\text { eliminated, redesigned, or automated; } 33.5 \\
\text { staff hours eliminated, redesigned, or } \\
\text { automated on a unit basis for four processes } \\
\text { and more. } \\
\$ 500,000 \text { in staff time saved over a year. }\end{array}$ \\
\hline $\begin{array}{l}\text { Solihull Borough } \\
\text { Council }\end{array}$ & Lean & $\begin{array}{l}\text { For the fostering service savings of } £ 500 \mathrm{~K} \\
\text { but } 25 \% \text { increase in fosters per month. } \\
\text { Reduce in post costs by } £ 135 \mathrm{~K} \text {. }\end{array}$ \\
\hline
\end{tabular}

Table 1: Examples and Impact of Lean Implementation in the Public Sector (Radnor, 2010) 


\begin{tabular}{|c|c|c|c|}
\hline HMRC Site & Staff Interviewed & HMCS Site & Staff Interviewed \\
\hline Chapel Wharf & $\begin{array}{l}5 \text { Managers } \\
\text { Local Lean Expert } \\
20 \text { Front Line Staff }\end{array}$ & $\begin{array}{l}\text { Southampton } \\
\text { Magistrates' } \\
\text { Court }\end{array}$ & $\begin{array}{l}8 \text { Managers } \\
2 \text { Legal Advisors } \\
9 \text { Team Members } \\
2 \text { Change Agents }\end{array}$ \\
\hline $\begin{array}{l}\text { NOS } \\
\text { Wolverhampton }\end{array}$ & $\begin{array}{l}4 \text { Managers } \\
\text { Local Lean Expert } \\
17 \text { Front Line Staff }\end{array}$ & $\begin{array}{l}\text { Cardiff Crown } \\
\text { Court }\end{array}$ & $\begin{array}{l}5 \text { Managers } \\
6 \text { Team Members } \\
1 \text { Change Agent }\end{array}$ \\
\hline $\begin{array}{l}\text { Child Benefit } \\
\text { Office }\end{array}$ & $\begin{array}{l}7 \text { Managers } \\
3 \text { Local Lean Expert } \\
21 \text { Front Line Staff }\end{array}$ & $\begin{array}{l}\text { Sefton } \\
\text { Magistrates' } \\
\text { Court }\end{array}$ & $\begin{array}{l}3 \text { Managers } \\
2 \text { Legal Advisors } \\
3 \text { Team Members } \\
3 \text { Change Agents }\end{array}$ \\
\hline Ipswich & $\begin{array}{l}3 \text { Managers } \\
3 \text { Local Lean Experts } \\
10 \text { Front Line Staff }\end{array}$ & $\begin{array}{l}\text { Salford } \\
\text { Magistrates' } \\
\text { Court }\end{array}$ & $\begin{array}{l}7 \text { Managers } \\
2 \text { Legal Advisors } \\
11 \text { Team Members } \\
1 \text { Change Agent }\end{array}$ \\
\hline Birmingham & $\begin{array}{l}4 \text { Managers } \\
2 \text { Local Lean Expert } \\
23 \text { Front Line Staff }\end{array}$ & $\begin{array}{l}\text { City of } \\
\text { Westminster } \\
\text { Magistrates' }\end{array}$ & $\begin{array}{l}3 \text { Managers } \\
5 \text { Team Members }\end{array}$ \\
\hline Lothians & $\begin{array}{l}5 \text { Managers } \\
\text { Local Lean Expert } \\
28 \text { Front Line Staff }\end{array}$ & $\begin{array}{l}\text { Leeds } \\
\text { Magistrates' }\end{array}$ & $\begin{array}{l}6 \text { Managers } \\
4 \text { Legal Advisors } \\
12 \text { Team Members }\end{array}$ \\
\hline South Wales & $\begin{array}{l}5 \text { Managers } \\
2 \text { Local Lean Expert } \\
24 \text { Front Line Staff }\end{array}$ & $\begin{array}{l}\text { Newcastle Civil } \\
\text { (County) Family }\end{array}$ & $\begin{array}{l}9 \text { Team Managers } \\
7 \text { Team Members } \\
1 \text { Change Agent }\end{array}$ \\
\hline $\begin{array}{l}\text { East Hampshire } \\
\text { and Wight }\end{array}$ & $\begin{array}{l}4 \text { Managers } \\
\text { Local Lean Expert } \\
\text { Trade Union Rep } \\
27 \text { Front Line Staff }\end{array}$ & $\begin{array}{l}\text { Milton Keynes } \\
\text { Magistrates' }\end{array}$ & $\begin{array}{l}3 \text { Managers } \\
7 \text { Team Members } \\
1 \text { Change Agent }\end{array}$ \\
\hline $\begin{array}{l}\text { West Yorkshire } \\
\text { and Craven }\end{array}$ & $\begin{array}{l}5 \text { Managers } \\
\text { Local Lean Expert } \\
32 \text { Front Line Staff }\end{array}$ & $\begin{array}{l}\text { Rhyl Civil } \\
\text { (County) Family }\end{array}$ & $\begin{array}{l}3 \text { Team Managers } \\
4 \text { Team Members } \\
1 \text { Change Agent }\end{array}$ \\
\hline \multirow[t]{4}{*}{$\begin{array}{l}\text { National } \\
\text { Insurance } \\
\text { Contributions } \\
\text { Office }\end{array}$} & $\begin{array}{l}2 \text { Senior Managers } \\
4 \text { Lean Experts } \\
2 \text { Managers } \\
2 \text { Local Lean Experts } \\
28 \text { Front Line Staff }\end{array}$ & $\begin{array}{l}\text { Luton Civil } \\
\text { (County) Family }\end{array}$ & $\begin{array}{l}\text { Area Director } \\
2 \text { Managers } \\
6 \text { Team Members } \\
1 \text { Change Agent }\end{array}$ \\
\hline & & $\begin{array}{l}\text { Birmingham Civil } \\
\text { Justice Centre } \\
\text { Civil (County) } \\
\text { Family }\end{array}$ & $\begin{array}{l}4 \text { Managers } \\
16 \text { Team Members } \\
1 \text { Change Agent }\end{array}$ \\
\hline & & $\begin{array}{l}\text { Coventry } \\
\text { Magistrates' } \\
\text { Court }\end{array}$ & $\begin{array}{l}2 \text { Managers } \\
\text { Legal Advisor } \\
6 \text { Team Members } \\
1 \text { Change Agent }\end{array}$ \\
\hline & & Stafford & 2 Managers \\
\hline
\end{tabular}




\begin{tabular}{|l|l|l|l|}
\hline & & Magistrates' & $\begin{array}{l}\text { 8 Team Members } \\
1 \text { Change Agent }\end{array}$ \\
\hline $\begin{array}{l}\text { Total number } \\
\text { of people } \\
\text { interviewed }\end{array}$ & 298 & & 183 \\
\hline
\end{tabular}

Table 2: Overview of the Interviews carried out in HMRC and HMCS 


\section{References}

Berry, L. L., E. A. Wall and L. P. Carbone (2006). "Service Clues and Customer Assessment of the Service Experience: Lessons From Marketing." Academy of Management Perspectives(May): 43-57.

Bhatia, N. and J. Drew (2007). "Applying Lean Production to the Public Sector." Mckinsey Quarterly(3): 97-98.

Bowen, D., Youngdahl, W., (1998). '"Lean' service: In defense of a production line approach." International Journal of Service Industry Management 9(3): 207-225.

Boyne, G., A (2002). "Public and Private Management: What's the difference?" Journal of Management Studies 39(1): 97-122.

Boyne, G., C. Farrell, J. Law, M. Powell and R. Walker (2003). Evaluating public sector reforms. Buckingham, Open University Press.

Carnall, C. A. (2007). Managing Change in Organisations. Harlow, FT Prentice Hall.

Christensen, T., Laegreid, P., (2001). "New Public Management." Public Management Review 3(1): 73-94.

Clark, G., R. Johnston and M. Shulver (2000). Exploiting the Service Concept for Service Design and Development. New Service Design. J. Fitzsimmons and M. Fitzsimmons. California, Sage Publications, : 71-91.

Davis, P. J. (2006). "In search of the common wealth: a service-profit chain for the public sector." International Journal of Productivity and Performance Management 55(2): 163-172.

Ding, D. X., P. Jen-Hwa Hu, R. Verma and D. G. Wardell (2010). "The Impact of Service System Design and Flow Experience on Customer Satisfaction in Online Financial Services." Journal of Service Research, 13(1): 96-110.

Edvardsson, B., B. Enquist and R. Johnston (2005). "Co-creating customer value through hyperreality in the prepurchase service experience." Journal of Service Research 8(2): 149-161.

Edvardsson, B., B. Enquist and R. Johnston (2010). "Design Dimensions of Experience Rooms for Service Test-drives - Case studies in different service contexts." Managing Service Quality 20(4): 312-327.

Edvardsson, B. and J. Olsoon (1996). "Kat Concepts for New Service Development." The Service Industries Journal 16(2): 140-164.

Ferlie, E. (2002). Quasi strategy: Strategic management in the contemporary public sector. Handbook of Strategy and Management. A. M. Pettigrew, Thomas, H., Whittington,R.,. Beverly Hills, Sage: 280-298.

Fillingham, D. (2007). "Can Lean Save Lives." Leadership in Health Services 20(4): 231-241.

Fujimoto, T. (1999). Organisational for Effective Product Development - The Case of the Global Automobile Industry. Boston, Harvard University Graduate School of Business Administration.

Gershon, P. (2004). Releasing Resources to the Front Line: Independent Review of Public Sector Efficiency, HM Treasury.

Goldstein, S. M., R. Johnston, J. Duffy and J. Rao (2002). "The service concept: the missing link in service design research?" Journal of Operations Management 20(2): 121-134.

Gremler, D. D., M. J. Bitner and K. R. Evans (1994). "The Internal Service Encounter." International Journal of Service Industry 5(2): 34-56.

Guthrie, J. (2006). The Joys of a Health Service Driven by Toyota. Financial Times.

H M Treasury (2009). Operational Efficiency Programme: Final Report. H. M. Treasury. London.

Heskett, J. L., T. O. Jones, G. W. Loveman, W. E. Sasser Jr and L. A. Schlesinger (1994). "Putting the Service Profit Chain to Work." Harvard Business review 72(2): 164-174.

Heskett, J. L., W. E. Sasser and L. A. Schlesinger (2003). The Value Profit Chain. New York, Free Press. 
Hines, P., M. Holweg and N. Rich (2004). "'Learning to evolve. A review of contemporary lean thinking"." International Journal of Operations and Production Management 24(10): 994-1011.

HM Treasury (2008). Operational Efficiency Programme: Prospectus. London, HM Treasury. Holweg, M. (2007). "The genealogy of lean production." Journal of Operations Management 25: $420-437$.

Johnston, R. (2008). "Internal Service - barriers, flows and assessment." International Journal of Service Industry Management 19(2): 210-231.

Krings, D., D. Levine and T. Wall (2006). "The Use of "Lean" in Local Government." Public Management 88(8): 12-17.

Lings, I. N. and G. E. Greenley (2005). "Measuring Internal Market Orientation." Journal of Service Research 7(3): 290-305.

Lusch, R. F., S. L. Vargo and M. O'Brien (2007). "Competing through service: Insights from service dominant logic." Journal of Retailing 83(1): 2-18.

MacGregor, D. (2001). Jobs in the public and private sectors. Economic trends. 571: 35-40.

Massey, A. (2005). The state of Britain: A guide to the UK public sector. London, Public Management and Policy Association.

Micheli, P. and M. Kennerley (2005). "Performance measurement frameworks in public and non-profit sectors." Production, Planning and Control 16(2): 125-134.

Mintzberg, H. and J. Bourgault (2000). Managing publicly. Ottawa, Institute of Public Administration of Canada.

Office of the Deputy Prime Minister (2005). "A Systematic Approach to Service Improvement."

Ohno, T. (1988). The Toyota Production System: Beyond Large-Scale Production. Portland, Productivity Press.

Olsen, L. L. and M. Johnson, D, (2003). "Service equity, satisfaction, and loyalty: From transaction-specific to cumulative evaluations." Journal of Service Research 5(3): 184-195.

Osbourne, D. and T. Gaebler (1993). Reinventing government : how the entrepreneurial spirit is transforming the public sector. Reading, Mass., Addison-Wesley.

Parente, D. H., C. C. Pegels and N. Suresh (2002). "An exploratory study of the salesprodcution relationship and customer satisfaction." International Journal of Operations and Production Management 22(9): 997-1013.

Piercy, N. and N. Rich (2009). "The implications of lean operations for sales strategy: from sales-force to marketing-force." Journal of Strategic Management 17(3-4): 237-255.

Piercy, N. and N. Rich (2009). "Lean transformation in pure service environment: the case of the call service centre." International Journal of Operations and Production Management 29(1): 54-76.

Pine, I., B. Joseph; and J. H. Gilmore (1998). "Welcome to the Experience Economy." Harvard Business Review, 74(4): 97-105.

Pollitt, C. (2003). New forms of public service: issues in contemporary organizational design. Governance in a world without frontieres. T. J. Couchene and D. J. Savoie. Montreal, Institute for Research on Public Policy (IRPP): 209-238.

Pollitt, C. and G. Bouckaert (2004). Public management reform: A comparative analysis Oxford University Press.

Prahalad, C. K. and V. Ramaswamy (2006). The Future of Competition - Co-Creating Unique Value with Customers. Boston, Harvard Business School Press.

Price, R. and R. J. Brodie (2001). "Transforming a Public Service Organization From Inside out to Outside in." Journal of Service Research, 4(1): 50-59.

Pritchard, M. and R. Silvestro (2005). "Applying the service profit chain to analyse retail performance: the case of the managerial strait-jacket?" International Journal of Service Industry Management 16(4): 337-356.

Radnor, H. (2002). Researching your own professional practice: Doing interpretive research. Buckingham, Oxford University Press. 
Radnor, Z. and P. Walley (2008). "Learning to Walk Before We Try to Run: Adapting Lean for the Public Sector." Public Money and Management 28(1): 13-20.

Radnor, Z. J. (2010). Review of Business Process Improvement Methodologies in Public Services, Advanced Instuite of Management.

Radnor, Z. J. (2010). "Transferring Lean into Government." Journal of Manufacturing Technology Management 21(3): 411-428.

Radnor, Z. J. and R. Boaden (2008). "Lean in Public Services - Panacea or Paradox?" Public Money and Management 28(1): 3-7.

Radnor, Z. J. and G. Bucci (2007). "Evaluation of Pacesetter: Lean Senior Leadership and Operational Management, within HMRC Processing." HM Revenues and Customs.

Radnor, Z. J. and G. Bucci (2010). Evaluation of Lean Programme in HMCS: Final Report. London, HM Courts Services.

Radnor, Z. J., M. Holweg and J. Waring (2011). "Lean in healthcare: The unfilled promise?" Social Science and Medicine forthcoming.

Rust, R. T., A. J. Zahorik and T. L. Keiningham (1995). "Return on Quality (ROQ): Making Service Quality Financially Accountable." Journal of Marketing 59(April): 58-70.

Seddon, J. (2004). Systems thinking and performance improvement in the public sector

Seddon, J. and C. Brand (2008). "Debate: Systems Thinking and Public Sector Performance." Public Money and Management 28(1): 7-10.

Shah, R. and Ward. (2007). "Defining and developing measures of lean production." Journal of Operations Management 25(4): 785-805.

Silvester, K., R. Lendon, H. Bevan, S. R. and P. Walley (2004). "Reducing waiting times in the NHS: is lack of capacity the problem?" Clinician in Management 12(3): 105-111.

Skalen, P. and T. Strandvik (2005). "From prescription to description: a critique and reorientation of service culture,." Managing Service Quality 15(3): 230-243.

Slater, R. (1999). Saving Big Blue. New York, McGraw Hill,.

Vandermerwe, S. (2004). "Achieving Deep Customer Focus." MIT Sloan Management Review 45(3): 26-34.

Vargo, S. L. and R. F. Lusch (2004). "Evolving to a New Dominant Logic of Marketing." Journal of Marketing 68(1): 1-17.

Verma, R., J. Fitzsimmons, J. Heineke and M. Davis (2002). "New issues and opportunities in service design research." Journal of Operations Management 20(2): 117-120.

Wilson, J. Q. (1989). Bureaucracy: what government agencies do and why they do it. New York, Basic Books.

Womack and Jones (1996). "Lean Thinking " Book Review in Financial Times 30th September 1996

Womack, J. and D. Jones (1996). Lean Thinking: Banish the Waste and Create wealth in your organisation. New York, Simon and Schuster.

Womack, J. P. and D. T. Jones (1996). Lean Thinking. London, Simon \& Schuster.

Womack, J. P., D. T. Jones and D. Roos (1990). The Machine That Changed the World. New York, Rawson Associates.

Zeithaml, V. A., M. J. Bitner and D. D. Gremier (2008). Services Marketing. New York, McGraw Hill.

Zomerdijk, L. G. and C. Voss (2010). "Service Design for Experience-Centric Services." Journal of Service Research 13(1): 67-82. 